УДК 821.163.41.09-32 Андрић И. https://doi.org/10.18485/godisnjak.2017.12.15

\author{
Небојша 3. Ђорђевић* \\ Универзитет у Београду \\ Филолошки факултет, студент
}

Оригинални научни рад

Примљен: 6. 10. 2017.

Прихваћен: 23. 10. 2017.

\title{
ФОЛКЛОРНИ ЕЛЕМЕНТИ У АНДРИЋЕВОЈ ПРИПОВИЈЕТКИ „МУСТАФА МАЏАР”
}

\begin{abstract}
Фолклор, као конститутивни дио српске културе, у значајној мјери конституише и обликује Андрићево стваралаштво. У стваралаштву Ива Андрића, елементи митолошке сфере фолклора врло изразито судјелују са пишчевом поетиком. На примјеру лика Мустафе Маџара можемо уочити и јачину универзалних симбола који су често амбивалентни. Промјене у овоме лику, али и промјене у његовоме односу према свијету и свијета према њему, одсликавају слој фолклорних елемената на којима дјело почива. И вријеме, и простор и дјелање јунака показују демонолошки подтекст Мустафина лика. Да овај наратив почива на фолклорном подтексту, недвосмислено нам показује крај текста и завршетак приповијетке, у којему је разрјешење у вези са митолошком сфером фолклора.
\end{abstract}

Кључне ријечи: фолклор, митологија, демонолошки елементи, архетипски образац, Мустафа Маџар, Иво Андрић

Епоха романтизма важна је за српску културу јер је у то вријеме побиједио став да је фолклор саставни дио нашег културног развоја, да представља високу умјетничку и националну вриједност и да је изворно богатство народног духа, што је у складу са хердеровском линијом која је на српску културу утицала преко њемачке културе. Ако бисмо ствари проматрали дубински видјели бисмо да фолклорни елементи који се транспонују у, прије свега, књижевни фолклор, а преко њега (али не и само

*djordjevicn95@gmail.com 
преко њега) у писану књижевност, долазе из елемената митолошке сфере фолклора. ${ }^{1}$ У своме раду о везама Ива Андрића и народне књижевности Светозар Кољевић дошао је до закључка да „,[...] вреди истаћи да је Андрић у обликовању свог романсијерског простора најснажније стваралачки опседнут оним подручјем народне усмене књижевности које бисмо могли одредити као свет предања, легенде и епске песме" (Кољевић 1981: 472) Наравно, ово бисмо могли да уопштимо на цјелокупан Андрићев приповједачки корпус. На примјеру приповијетке „Мустафа Маџар”2 јасно се види спрега поетике Ива Андрића и фолклорних елемената карактеристичних за ову приповијетку.

\section{1. Лик Мустафе Маџара - поетика времена и простора}

Разноврсност у тематици, обликовању и разради саме тематике, начину приповиједања, перспективи и фокализацији нарације, као и разнородност у мотивском погледу, неке су од одлика прве Андрићеве збирке приповиједака. Приповијетка „Мустафа Маџар” долази из корпуса који је тематски везан за „живот муслиманско-турског живља, у његовој етнографско-историјској шароликости" (Вучковић 2011: 202). Андрић је тематику у првој својој збирци приповиједака развијао у неколике правце: поред развијања тематике у правцу репертоарске скице, без нарочитих заплета, са тежиштем на оцртавању атмосфере, а у вези са пишчевим непосредним доживљајима у дипломатској служби (,Дан у Риму”, „Ноћ у Алхамбри"), као и у правцу анегдотског заплета са хумористичном поентом („,У зиндану”), приповијетка „Мустафа Маџар” припада опсежнијем и комплекснијем обликовању која се сврстава у повијести „о болесним нагонима и стањима људске свести који воде у злочин и смрт” (Кољевић 1981: 472). Настављајући даље о тематској устројености прве Андрићеве збирке приповиједака, Радован Вучковић пише: „У две приче, „За логоровања” и „Мустафа Маџар”, које представљају почетак Андрићевог приповедачког рада о крволоцима и страви морбидних извитоперених

\footnotetext{
${ }^{1}$ Једна струја истраживача фолклора поријекло приповиједака види управо у митологији. Подробније о томе видјети у: (Милошевић-Ђорђевић 2006: 7-22).

${ }^{2}$ Андрић је ову приповијетку први пут објавио 1923. године у Српском књижевном гласнику, књ. 8, бр. 1, (јан.-април 1923), стр. 1-15, да би је потом, 1924. године уврстио у своју прву збирку приповиједака „Приповетке”, у издању Српске књижевне задруге, коло 27, број 179, стр. 53-69; у: Библиографија Иве Андрића (1911-2011), 2011: 211; 19.
} 
нагона ${ }^{3}$, позитивног решења нема" (Вучковић 2011: 202) 4 . Требало би се запитати какво разрјешење би могло да се уклопи у хоризонт очекивања о којему Радован Вучковић пише. Вјероватно се то односи на поетику послијератног експресионизма, чији утицај можемо уочити у стилској динамици ових приповијетки израженој у напетости емоција у јунака. Жељећи да се утопи у дух општеевропске послијератне књижевности, Андрић приказује тајанствене и романтичарске снажне личности пустахија, какве можемо сусрести у прози њемачког експресионизма (в. Вучковић 1975: 205-233). Ако перспективу проматрања измјестимо, а „Мустафу Маџара" посматрамо у фолклористичком кључу, можемо одмах закључити да „Позитивног рјешења" не може и не треба да буде, јер је разрјешење приповијетке у функцији одсликавања природе самога јунака, о чему ћемо касније у раду подробније и прецизније говорити.

\section{Мустафа и свијет - свијет и Мустафа}

Најприје би требало одредити мјесто лика Мустафе Маџара у свијету истоимене приповијетке. Његов однос према друштву, као и однос друштва према њему, недвосмислено нам указује на то да се Мустафа налази на рубу друштвене егзистенције. Посриједи је својеврсна митизација и мистификација његове личности као такве, али и као носиоца херојскога апсолута. Његов положај можемо посматрати кроз неколике сфере друштвеног живота, али и неколике сфере онтолошког егзистирања. Мустафа се налази на додиру граница двају свјетова. С једне стране, он коегзистира између свијета „крштених” и свијета „некрштених”, док с друге стране он коегзистира између онога људскога у себи и онога елемента у себи који припада демонолошком свијету.

Ако аналитичкосинтетички приступимо уводним реченицама приповијетке можемо да уочимо да се фолклорни елементи недвосмислено појављују, али само ако у виду имамо фолклористичко читање приповијетке: „Са свитањем сиђоше бубњари из махала и стадоше се сакупљати коњаници који ће ићи у сретање” (Андрић 1981: 23). У народној традицији Словена два основна својства ноћи јесу тишина и тама. Језгро ноћи у народним причањима није означено само као тамно или мрачно, већ

${ }^{3}$ Петар Џаџић одлази корак даље у одређивању Мустафе Маџара. Џаџић пише да поред тога што Мустафу испуњава осјећање егистенцијалне нелагосности, поред тога што увиђа да овог крволока прожима стрепња, неоправдано га квалификује као „крволока садистичконекрофилног усмерења" (Џаџић 1996: 317).

${ }^{4}$ Сви курзиви у раду курзиви су аутора овога рада. 
и као глуво доба. У вези са тим, можемо закључити да се тишина узима као једно од својстава ноћи. Одсуство звукова узрујава човјека, па страх расте управо пропорционално са тишином. Глуво доба, које је тријумф мистериозног интервала ноћи, не завршава се само разбијањем таме, већ и разбијањем тишине. „Продорни гласови сеоских петлова као да су моћнији и од Сунца” (Братић 1993: 55-56). У том кључу, почетак Андрићеве приповијетке одсликава скривени слој фолклора који је укалупљен у слику бубњара који дочекују славнога добојског јунака из боја. Поред „спољашње стране” ове приповијетке, поред „званичне (псеудо)историје” у којој је „Ово [...] четврти дан да Добој шенлучи и слави побједу над Аустријанцима код Бањалуке. Ликовала је сва Босна, али Добој нарочито, јер је њихов мјештанин Мустафа Маџар био највећи јунак у бањалучком боју" (Андрић 1981: 23) наилазимо на фолклорни подтекст у којему су становници Добоја дистанцирани од свога мјештанина Мустафе. То дистанцирање огледа се на реторичкој равни ${ }^{5}$ као и на „онтолошкој” равни. „Онтолошка раван” подразумијевала би то што би се на Мустафу гледало као на онтолошки, квалитативно друго или бар другачије биће. Исказом: „Тек око ићиндије ${ }^{6}$ стигоше први коњаници [...], а у сам акшам ${ }^{7}$ Мустафа Маџар с трубама и барјацима" (Андрић 1981: 23) поступци Добојлија сврставају се у поступке колектива у свакодневном животу, према којему је „дан радуша, а ноћ спавуша” (Братић 1993: 23); граница између таме и свјетлости прецизно је одређена звуком јутарњих пијетлова, „гласницима дана", те се човјеку оглашава у којему тренутку престаје ноћ и почиње нови дан. ${ }^{8}$ То видимо тако што наративна инстанца указује на њихову активност одредницом „са свитањем”. Насупрот њима, активност Мустафе Маџара наративна инстанца обиљежава одредницом „у сам акшам”, којом се показује да биће дјела у дијелу дана који почиње по акшаму, односно по вечери. Амбивалентност демонолошких бића огледа се у томе да поред тога што им прија тишина (вјерује се да „ђаволи воле ноћну тишину, боје се лавежа паса и кукурикарања” (Братић 1993: 56), односно „тишина је [...] сигуран показатељ да људска заједница није ту и да онострано може

\footnotetext{
${ }_{5}^{5}$ Дуалном фокализацијом или реториком контраста, сасвим индикативно, колективна перцепција у причи о Мустафи Маџару одвојена је од непосредно-исказне перспективе наративне инстанце. Такође, именовање носилаца двију перцепција јасно је уочљиво: „Добој” наспрам „њиховог мјештанина”, што нам показује колико је истакнуто диференцирање, али и то како се приповједач са свезнајуће-неутралне премијешта у персонално-колективну перспективу.

${ }^{6}$ Ићиндија - поподневна молитва (Андрић 1981: 348);

${ }^{7}$ Акшам - вече; вечерња молитва код муслимана (Андрић 1981: 347);

${ }^{8}$ О одређивању времена у народној религији Срба видјети у: Братић, 1993: 21-54.
} 
да врши своју глуву делатност" (Братић 1993: 56), нека од њих карактеристична су по томе што своју присутност оглашавају различитим звуцима, дреком, према којима су и добили име: дрекавац, букавац, плакавац и свирац (в. Зечевић 1981: 123-126). Исказ да је „несносна дрека некритенаи $a^{9}$ увек [...] злосутна, јер најављује смрт" (Братић 1993: 57), да се некрштенци оглашавају звуком „који долази 'с оне друге стране'”(Братић 1993: 56), у потпуности одражава поједина дјелања Мустафе Маџара, као и фолклорни подтекст цијеле приповијетке. Његов долазак у Добој праћен трубама дијаметрално је супротан завршетку приповијетке. Да се Мустафа „оглашава” ноћу, дознајемо из још једног мјеста у приповијетки: „Касно y ноћи потражи своју зурну [...] и дуну плашљиво и ниско: [...] Тишина прими непријатно звук" (Андрић 1981: 24). Раскид таме и тишине која „непријатно прими звук” амбивалентан је и у складу са епистемологијом модерног субјекта: раскид таме представља и раскид њега сама, унутрашњи раскол који све више долази до изражаја - подвојеност на људско и нељудско. Управо та дистинкција имаће пресудну улогу у разрјешењу приповијетке. Оглашен трубама и зурном, Мустафа је у противтежи са колективитетом Добоја, а као такав он представља пријетњу за њих. Дио у којему плашљиво свира зурну показује његову рањивост, али у исто вријеме и поменуту опасност по колективитет. Демонолошки моменат у његовом бићу чини га надмоћним у односу на становнике Добоја, али га његов људски моменат чини рањивим у односу на онострана бића.

Елиптична реторика приповиједања у дијелу који се односи на поријекло Мустафино, особена је Андрићевом стилу. Од оца „расипника и пијанице, иако му је дјед Авдага Маџар, чувени потурчењак из старе и угледне мађарске фамилије”. Мустафи је „кад му је било петнаест година, отац [...] умро, а брат му се оженио” те га „послаше [...] у Сарајево да учи медресу. Ту проведе четири посне и тешке године. У двадесетој години, са сандуком књига и софтинске сиротиње, и с великом зурном од црна дрвета [...] врати се у Добој [...] Био је сасвим промијењен” (Андрић 1981: 24). У приповијетки „Труп” Андрић је искористио други израз за исту појаву која је задесила Челеби-Хафиза; промјена коју је освједочио наратор у тој приповијетки била је тако нагла, дошла је „одједном, али то одједном: као млијеко кад се провари” (Андрић 1988: 97). Таква врста изненадне промјене баца сјенку на саму промјену јунака, али је значајан индикатор да се (у) јунаку нешто догодило. О поријеклу и предисторији

${ }^{9}$ Као некога ко припада исламској вјероисповијести, некога ко није крштен, Мустафу Маџара бисмо у свјетлу контекста у којему ћемо га тумачити, могли метафорички назвати некрштенцем. 
Мустафе Маџара сазнајемо од наративне инстанце, што значи да немамо прави увид у догађаје и доживљаје самога јунака прије него што се са њим сусрећемо при доласку у Добој. Овакав поступак Андрићева приповиједања карактеристичан је и за друге његове приповијетке, а нарочито за фратарски циклус.

\section{Јачина симбола - демонолошки одсјаји}

Унутрашња борба самога Мустафе исказана је неколиким значењским слојевима. Ако говоримо о поетици простора, важну улогу има мјесто на којему се Мустафин чардак налази: „Ово је по трећи пут да се Мустафа враћа у свој чардак понад воде” (Андрић 1981: 23). Симболика воде у поетици послијератног експресионизма који је имао утицај на ране Андрићеве приповијетке била је у свих писаца тога доба мање или више једнака. С друге стране, симболика воде која има велики семантички потенцијал, а која се огледа у структури ове приповијетке, своје поријекло води из фолклора Словена. Поред симболике која је значајна за обредне сфере народног живота у којој су у првом плану природне особине воде (провидност, свјежина, брзо протицање, способност очишћења), вода често има другачију симболику која се односи на „туђи свијет”, свијет за који је вода улаз. Водени простор осмишљен је као граница између овостраног и оностраног свијета, свијета људи и свијета у којему бораве нечисте силе (в. Толстој - Раденковић 2001: 87). „Нечисте воде” у Срба представљају станиште демона (в. вода код Кулишић - Петровић - Пантелић 1970). Но, вода представља и „симбол несвесних енергија, безобличних сила душе, тајновитих и непознатих могућности” (Гербран - Шевалије 2009: 1055). Мустафина веза са водом вишеструка је, ${ }^{10}$ а прије свега подстицајна у смислу његових јуначких атрибута, као и у процесу његове јуначке иницијације. Наиме, у дијелу приповијести у којему је Мустафа у борби „прескакао [...] са сплава на сплав као крилат. Изгледао је као да лети изнад воде" (Андрић 1981: 26). Његова снага и поступци могу се приписати натприродном јунаку. Његова повезаност са водом

\footnotetext{
${ }^{10}$ Ако обратимо пажњу на лик Арапина из пјесме „Марко Краљевић и Арапин” (Антологија народних песама о Марку Краљевићу, 2005: 387-398) можемо увидјети сличности са ликом Мустафе Маџара. Арапин као демонска фигура своје станиште изграђује „украј сињег мора дебелога”. Његовоме јунаштву и силини није раван ни сам цар од Стамбола, што је слично снази коју у Добоју угледа Мустафа. Ова паралела само је једна од могућности проналажења сличности између Мустафе Маџара и епских јунака који су оличење демонских фигура. За ову пјесму одлучили смо се зато што представља репрезентативну поредбу која је лако уочљива и на тематском-мотивско плану.
} 
дјеловала је кроз изражај највиших могућности јуначкога момента у његовом лику. Посебност његове јуначке индивидуе посебно је исказана у дијелу у којему Мустафа „достиже посљедње [Аустријанце], упада међу њих, окреће се стреловито, а завитлана сабља му шири свијетал круг и хладан вјетар око њега" (Андрић 1981: 27).

И у Мустафином поимању времена, ноћ је доба које представља многе потешкоће. Борба која се одвија у његовом бићу (тачније, борба која се одвија између два пола његовога бића) оспољена је и сваке сљедеће ноћи одузима онај дио бића у којему почива његов људски елемент. Мустафу мучи бесаница, која га обузима сваке ноћи, те он „одједном заборави све што је икад било, и своје рођено име, и пошто се тако у првом полусну угаси свако сјећање и свака помисао на сутрашњи дан, и остане само склупчано тијело под тамом као нијемим жрвњем, отпочну брзи мравци уз ноге и стрепња у мекоти испод срца, и стане свуда да се шири страх као хладно струјање. С времена на вријеме ваља да устане, [...] да пали свјетло и отвара прозор, да се увјери да је жив, да га нису сатрле и разнијеле мрачне силе. Тако до зоре, кад у тијело уђе тежак мир...” (Андрић 1981: 24-25). Таму која обузима мекоту испод његовога срца Мустафа разбија паљењем свјетла и провјетравањем ${ }^{11}$, а свитање нове зоре поништава дејство ноћи које све више оставља трага на Мустафу и одузима ту мекоту која га одржава у животу међу људима. Када би се овом дијелу наратива приступило психоаналитички, видјели бисмо да бисмо дошли до одређених тумачења која би освијетлила лик Мустафе Маџара. Али, ако томе приступимо из угла фолклорних елемената, можемо уочити да се долази до истих тумачења. Немири који обузимају Мустафу посттрауматска су посљедица његових бојева, али свакако јесу елементи народне религије који у духу фројдовске психологије показују борбу за душу. Ту борбу ће Мустафа изгубити. А снове које сања ${ }^{12}$ можемо посматрати кроз призму

${ }^{11} \mathrm{У}$ народним вјеровањима ваздух и вјетар имали су улогу у избављењу од болести, а такође односе и „нечисти”. Код Бјелоруса постоји изрека „Иди невољо уз вјетар”, док се у Бугара каже „Вјетар те донио, вјетар те однио” (Толстој - Раденковић 2001: 76-77, одредница: „Ветар”).

${ }^{12}$ У овој Андрићевој приповијетки сан има архетипску димензију (Rečnik književnih termina, 1986: 692). Мустафа сања руску дјецу са Крима коју је његов одред, састављен углавном од Анадолаца, „преметао из руке у руку до јутра”, а онда, под налетом Руса, не стигавши „ни да покољу” ту дјецу, узјахаше коње и одоше. Несумњиво је да у првом слоју снови представљају одраз душевних немира, посљедицу злокобних дјела - једном ријечју, гризодушје! Да се психоаналитички моменат појача, Андрићев наратор снове исказује експлицитније и са више психоаналитичких елемената: Мустафи у сну „као увијек кад се најмање нада, изађоше преда [...] она дјеца с Крима, плава и пошишана, али некако крута и глатка и снажна, па се измичу као рибе" (Андрић 1981: 33). Мотив рибе у сну јасна је индикација нечисте савјести, 
народне традиције и фолклора у којима снови представљају метафоричку пројекцију догађаја са непријатним и фаталним исходом, доносе свијест о неизбјежности смрти и крају јунака који снива његова љуба или он сам (в. Пешић - Милошевић-Ђорђевић 1997: 232-233).

Постепени прелаз од људског ка нељудском Андрић је извео дехуманизацијом, односно анимализацијом Мустафе Маџара. То је моменат када у њему надвладава оно што није људско. Он тада постепено постаје демонска фигура. „Видећи [...] да више нема миран сан ни пред зору, јекну од немоћна бијеса, сави се и стаде да бије главом о земљу. Тако се дуго бамао и режећи, вас запјењен, гризао црвену кабаницу, док се дизало сунце, над планином, високим небом" (Андрић: 32). Послије момента у којему нам је постало јасно да се Мустафа неповратно мијења, досљедна анимализација Мустафина лика прераста у његову демонизацију; на лажи Абдуселамбега ${ }^{13}$ „Маџар само фркће и одихује”, а кад „бег изрони из својих лакрдија” соба му се чини мрачнијом, свијећа се повија и титра под његовим дахом, а „сасвим близу види два неједнака, закрвављена и опасно свијетла Мустафина ока..." (Андрић 1981: 35). То што Мустафа убија бега који лажно хвали себе, својеврсна је потврда да је свијет Мустафе Маџара херојски свијет у којему се ријеч није одвојила од истине, а ако се одвоји, као што је то учинио бег, тај преступ бива санкционисан. Са појавом модерне, ријеч се одваја од истине, а херојски свијет престаје да постоји. ${ }^{14}$

Да су Мустафу демонски елементи запосједали све више, али не и потпуно запосјели, показује нам и дио у тексту у којему је Мустафа послије

\footnotetext{
али је и одраз који из психоанализе примјењују послијератни писци згрожени ратом који до тада свијет није видио. Поред снова о дјеци са Крима, Мустафа сања и друге своје жртве, које у његовим сновима заузимају фигуру прогонилаца. Ако погледамо ликове који су представници средњоевропске грађанске интелигенције, попут Крлежиног Леона Глембаја, видјећемо да нечиста савјест представља лајтмотив и терет послијератним писцима. Леоне такође у „Господи Глембајевима" сања рибе, а његова дефиниција средњоевропског интелектуалца свела би се на ријеч überspannt (пренапет), којом је и дефинисан у овој драми. Напетост је особина и Мустафе Маџара. Заточен у опсесивном извршењу злочина, унутрашњом принудом приморан да чини што чини, Мустафа постаје жртва властитих злочиначких нагона (Ахметагић 2011: 281-282), те он постаје прогоњен жртвама из својих снова.

${ }^{13}$ Мустафа је на бега наишао у близини Омерова хана, а бег га је „заустављао на све начине да с њим преноћи, рачунајући да сутра стигну у Сарајево и да свијет и знанци виде кад уђе с Мустафом Маџаром као другом и сапутником” (Андрић 1981: 33). Ова похвала јунаку Мустафи, поред оне на почетку у којему га Добојлије свечано дочекују, у контрасту је са крајњом „демитизацијом апсолута херојства” (Вучковић 2011: 208) и детронизацијом Мустафе Маџара.

14 У „Лажном цару Шћепану Малом” Његош је дотакао срце ове проблематике и наговијестио модерну у српској књижевности; в. Ломпар 2008.
} 
убиства Абдуселамбега коњем кренуо пут Сарајева. „Те ноћи путоваше без престанка кроз шуму. Коњ му је застајкивао од умора и зазирао од сјенки. Тада и он поче да посматра чудне облике осамљених пањева и њихових сјенки у свијетлој ноћи без видљива мјесеца. Презаше и заобилажаше оне који су имали опасан и чудан став. Наједном му се учини као да уз сваки облик иде и нарочит глас, шапат, дозив или пјевање; тихи, једва чујни гласови који се измјењују и преплићу с облицима. Сви утонуше у пуцању канџије којом је шибао коња. Али чим би престао да шиба, стадоше гласови да се роје и наваљују. Да би их опет ушуткао, он викну и сам: / - Аааа! / Али тад му шума са свих страна, из свих шупљина и са сваког стабла и листа, одговори још јаче и надвика га и засу гласовима. / - Аооо!” (Андрић 1981: 36) Простор шуме јасно је дефинисан у нашем фолклору и нашој усменој епици: као мјесто које је ненасељено људском заједницом, као мјесто које се налази „споља” у односу на мјесто живљења које је „унутар” заједнице, шума је недвосмислено хтонско мјесто. Шума, као и вода, потврђује својим „дјеловањем” карактеристике пограничног локуса. Ова црта митологије шуме одржава се у сижеима општесловенских предања: човјека који се обрео, задржао или залутао ноћу у шуми нечисте силе увлаче у демонску мистификацију (в. Толстој - Раденковић 2001: 161, одр.: „Дрво”). Систем пограничних простора који чине поетику простора приповијетке „Мустафа Маџар” досљедно се одсликавају на лик Мустафе Маџара и досљедно чине његову егзистенцију пограничном, што је кључно да разумијемо.

Да Мустафа није потпуно запосједнут, можемо уочити и у дијелу прије убиства бега: „[...] пође низ брдо водећи коња са собом. Заустави се тек кад стиже у равницу, крај чесме, млаз воде, свијетал, и дебео као рука, падао је у корито од издубљена бора. Вода се прелијевала и нашироко натапала земљу и стварала локве и плитке баре, изнад којих су титрали, у јутарњем сјају, лептирови и густи ројеви мушица као немирни велови. Коњ је дуго пио, топећи копита у локви и подрхтавајући мишићима на стегнима и боковима, а он [Мустафа] је сједио на рубу дрвеног корита, некако занесен и стишан свјежином воде ${ }^{15}$ и јутарњег зрака на лииу. Тада се угледа у води и видје лице осјенчено, као угљен тамно...” (Андрић 1981: 32). ${ }^{16}$ Амбивалентна природа воде у овом дијелу не само да представља

\footnotetext{
${ }^{15}$ Сјетимо се само да је свјежина једна од природних особина воде која је изражена у обредној сфери народног живота, а која своју улогу налази у процесу лустрације (Толстој -Раденковић 2001: 87, одредница: „Вода”);

${ }^{16} \mathrm{O}$ вјеровању да је огледање у води ризично, те да је према једној варијанти предања о настанку ђавола Бог оживио лик у води, а тај оживјели створ почео је кварити послове Богу,
} 
хтонско погранично мјесто ${ }^{17}$, већ своје значење испољава и у својему лустрационом потенцијалу (в. Толстој -Раденковић 2001: 88, одредница: „Вода”). ${ }^{18}$ Оваква амбивалентност значајна је и из угла поетике модернизма у којој промјенљива епистемологија модернога субјекта, који је сада конструкт изложен и лако подложан мијењањима, одсликава своју подвојеност. Такође, амбивалентна природа воде показује и то колико је вода јак симбол.

\section{Демонска фигура, добар коњ и свијетло оружје}

Мустафа Маџар у приповијетки приказан је као лик са одређеним особинама епског јунака, а неизоставни дио обликовања његовога лика јесу оружје и коњ. ${ }^{19}$ Својства натприродног јунака који је непобједив у рецепцији његових мјештана допринијела је свакако Мустафина сабља. Мустафа се у боју „окреће [...] стреловито, а завитлана сабља му шири свијетал круг и хладан вјетар око њега" (Андрић 1981: 27). Поред сабље, као убојито оружје Мустафа посједује и пушку којом убија Абдуселамбега. Коњ, вјерни слуга и помоћник своме господару, неизоставни је дио као и оружје. У народној традицији, коњ је један од најмитологизованијих животиња. Као главна транспортна и теглећа марва, ова животиња оличава везе са свијетом натприродног (в. Толстој - Раденковић 2001: 280, одр.: кою), а тиме показује и изузетност јунака којему припада. Мустафин коњ поред дијела у којему се одмарају поред чесме, представљен је и

па је Бог створио човјека, супарника непослушног створа, ђавола; в. Кулишић - Петровић - Пантелић, одредница: „Баво”.

${ }^{17}$ У овом смислу је то изражено у мотиву огледања јунака и уочавању затамњености његовога лица, што је знак демонског преображења.

${ }^{18}$ Лустрациона и апотропејска семантика воде уочава се у многобројним ритуалима шкропљења, умивања, купања, поливања, пијења посебне („набајене”) воде. Словени су водом полијевали болеснике (уп. словеначке баладе о Rošlin in Vrjanko у којима мајка, правећи се да је болесна, шаље сина Врјанка на љековиту воду гдје га у засједи чека Рошлин, мајчин љубавник и муж, убица његовога оца: Пешић -Милошевић-Ђорђевић 1997: 21, одредница „Rošlin in Vrjanko”) или људе који су починили гријех. Традиционална добродошлица Источних Словена изражавана је формулом: „Буди здрав, као вода”.

${ }^{19}$ Као примјер за јунаково оружје и коња узећемо Марка Краљевића јер је његова епска биографија најопширија и најразвијенија. О Шарцу Марка Краљевића испјеване су чак и посебне пјесме. Поред напомена из Вукових збирки и Пјеснарице (В.Вук С. Караџић, Пјеснарииа 1814-1815, 1965: 106, и: Вук С. Караџћ, Српске народне пјесме, књ. II, 1988, напомене уз пјесму бр. 70), о Марковом Шарцу постоји пјесма и у Ерлангенском рукопису (пјесма под бројем 83). Детаљно о оружју и коњу у пјесмама о Марку Краљевићу видјети у регистру коња и оружја у: Антологија народних песама о Марку Краљевићу, 2005: 565-566, подробније о оружју и коњу Марка Краљевића видјети у: Златковић, 2011: 21-34, систематично и опширно о оружју и коњу као епским атрибутима писано је у: Самарџија 2008: 40-78. 
као слабашно кљусе, изморено и оронуло под теретом демонског јунака: „Под њим је сваки час посртао коњ раскрвављених цјеваница и упалих бокова" (Андрић 1981: 36).

Испољавање својстава демонске фигуре можемо уочити и у дијелу у којему Мустафа Маџар своју злу и немилосрдну ћуд испољава на немоћним фратрима који су пред њим понизни. Демонски елементи који могу да се уоче огледали би се у томе што јунак те величине и снаге кињи слабије од себе; кињи их не са неким одређеним циљем, већ због сопственог незадовољства. Када им каже да баце фермане које имају од султана, везира и од муле из Сарајева, Мустафа додаје и ово: „А ако те ко упита шта то радиш, реци: наредио ми Мустафа Маџар, који се одвалио као стијена низа страну, па нит му треба сна ни хљеба, нит признаје закон” (Андрић 1981: 30). Изразом „одваљен као стијена” Мустафа је осликан као снажна фигура која више не хаје за закон. Разлика од Мустафе који је славни јунак, херој у бојевима, до фигуре самовољца, приказана је поступно. Његово залажење у зло је све веће. То примјећују и фратри који „слуте зло већ по [Мустафином] избезумљеном и укоченом погледу...” (Андрић 1981: 30).

Да се процес демонизације при завршетку приповијетке окончава у корист демонских елемената, јасно је по изгледу Мустафе који је од јунака који сабљом шири свијетли круг и вјетар око себе до јунака који је ,згужван, каљав, несигурно ступа кроз помрчину која му је на очима" (Андрић 1981: 37), „вас раскидан, умрљан травом и жут од иловаче. Таман као угљен у лииу [...] очи сасвим залијевене крвљу, у којој је остала зјеница само као црна тачка у средини..." (Андрић 1981:38). Упркос борбама које су биле неизвјесне, Мустафина трансформација сада је била потпуна. Ступањем кроз помрчину која му је у очима, Мустафа ступа у зло, прихвата своју демонску природу. Иловача којом је упрљан, тамна боја лица која је поређена са угљеном, предочавају његову завршну етапу у приступању злу - његово мјесто више није међу људима, његов свијет сада једино може да буде онострани. Мустафа је и на том путу заустављен, убијен, а његов свијет остао је у пограничном дијелу двају свјетова. Девизом: „И крштеног и некрштеног: свијет је пун гада!” (Андрић 1981: 38) којом је изазвао реакције Турака у кафани, Мустафа је експлицитно одредио своје мјесто, онтолошко, али и културолошко. Он више нигдје не припада! Антополошки песимизам који је исказан у наведеној девизи само појачава његову издвојеност од људи и од свијета.

Заподјенувши кавгу у механи Мустафа „као слијеп потрча на улицу. Турци за њим” (Андрић 1981: 38). Као јунака који је „одваљен од стијене”, као натприродно биће са демонским елементима у себи, Мустафу Турци нису могли да савладају. Њему у крај могло је изаћи само биће слично њему 
(које је на граници свјетова) или пак биће које је у потпуности у вези са оностраношћу. Разрјешење ове приповијетке, као и конац живота Мустафе Маџара, посљедица су активности бића за које бисмо могли да кажемо да је двоструким везама везано за демонолошки свијет. „Иако сасвим изван себе, он [Мустафа] није подлијегао ударцима и трчао је много брже од њих [...] кад из једне ковачнице изиђе Циганин и, видећи да гоне полунага човјека, баци се на њега комадом старог гвожђа, погоди га у сљепоочницу и обори на мјесту" (Андрић 1981: 39). У народној традицији ковачки занат сматран је великом вјештином, а у вези са натприродним знањима, чарањима, која подразумијевају и комуникацију с нечистим силама, па чак и ђаволом (в. Толстој - Раденковић 2001: 271, одр.: ковач). По српском народном предању, ковачки занат је измислио ђаво, а слично је вјеровање и у других балканских народа. Овим занатом су се углавном бавили Роми, чије је поријекло у вјеровањима, такође у вези са ђаволом. Некад се ковач идентификовао са фигуром ђавола, односно, мислило се да је у вези са демонима доњег свијета (Кулишић - Петровић - Пантелић 1970: одр.: ковач). Својом тамном пути, због које је ушао у народна вјеровања (Кулишић-Петровић - Пантелић 1970: одр.: циганин) Циганин представља демонског противника који може да се избори са Мустафом, а та његова демонска предиспозиција појачана је сазнањем да је он ковач.

„Мрак и тврдо. Тврдо. То је било посљедње што је осјетио” (Андрић 1981: 39). За Мустафу Маџара није било рјешења о којему је Радован Вучковић писао, зато што је сукоб Мустафе Маџара од почетка приповијести о њему био спољашње природе. Да је био неповратан јасно је из тога што је тај сукоб потпомогнут унутрашњим сукобом који је свакако претходио спољашњем. Борба његове људске стране са оном која је демонска, нељудска, све више се оспољавала, да би га на крају потпуно трансформисала у демонску фигуру. Посљедњом реченицом „Прогонитељи су пристизали” (Андрић 1981: 39) одражено је мјесто у којему се Мустафа налазио током читаве приповијетке: он је био и фигура заштитника и демонска фигура у исто вријеме, прогоњени и прогонитељ. Прогонитељи из његовога сна најзад су га сустигли. Погранична позиција његовога бивствовања запечаћена је и овјековјечена с концем његова живота.

Поред утицаја фолклора на тематско-мотивски склоп ${ }^{20}$ ове приповијетке, можемо уочити бројне сличности са поетиком књижевног

\footnotetext{
${ }^{20}$ Оно што није наведено у пређашњој анализи, а требало би споменути, јесте то да и симболика броја три има своје мјесто у приповијетки. Мустафа Маџар се три пута враћа у своју кућу понад воде. Са сваким повратком његова реинтеграција у живот мјештана градацијски је бивала све тежа. (О обредима прелаза, нарочито обредима одвајања, обредима прикључења
} 
фолклора. На самом почетку приповијетке сазнајемо понешто о изгледу Мустафе Маџара, као и то какав је хоризонт очекивања мјештана у вези са тим. „Бијаше погнут и некуд мален (јер у причањима и очекивању бијаше порастао)" (Андрић 19981: 23). Познато нам је да је Андрић гајио интересовања и симпатије према поетици причања. Поетика гласина, преношење поруке са уста на уста, познати је механизам, уједно и особеност усмене комуникације. У књижевном фолклору „настајање и извођење творевине прати - слуша већи број потенцијалних преносилаца, који и сами у некој следећој прилици могу да се нађу у улози певача/приповедача" (Самарџија 2007: 15). У поменутом дијелу из приповијетке јасно је да је ријеч жива ствар и да она кружи међу мјештанима. Раздор између реалистике и очекивања одсликава лице и наличје самога јунака. На неколиким мјестима у тексту поетика гласина вјерно одсликава поетику умјетности усмене ријечи. „Једне године се пронесе глас да је погинуо” (Андрић 1981: 24), „Дођоше и опет гласови о његовим јунаштвима" (Андрић 1981: 25), а насупрот томе „прича се”, на једном мјесту налазимо: „Дуго се не чу ништа" (Андрић 1981: 24).

„Животни пут Мустафе Маџара на специфичан начин илуструје неке од елемената познатог, широко распрострањеног мита о јунаку, односно неке од особина јунака, хероја као архетипског карактера. Али, управо онда када ова личност треба да се дефинитивно формира као јунак - у току самих јуначких подвига и после њих - наступа њено потпуно психичко растројство, неспособност владања нагонима, отворен сукоб са околином и незаустављива агресија на све живо на свету, „било то пас, кокош или човјек” (Шутић 1981: 283). Према том обрасцу, Мустафа Маџар се, изгубивши себе, одбио и од других људи (в. Самарџић 1981: 273). Мит о јунаку „о коме се толико причало и пјевало” (Андрић 1981:24) саткан је од расцјепа стварности и привида.

Да је у основи приповијетке и фолклорни подтекст, недвосмислено су показали елементи који су интегрисани у архетипске обрасце, психоаналитичке представе о Мустафи, као и историјске потке које је Андрић користио. ${ }^{21}$ Иницијација којом је Мустафа пролазио водила га је ка демонској природи његовога бића. Да је живио на граници двају свјетова, можемо закључити на основу хронотопа, али и саме поетике простора. Демонској фигури каква је Мустафа могла би да опонира једино демонска

тј. придружења и обредима реинтеграције видјети у: Арнолд ван Генеп, Обреди прелаза: систематско изучавање ритуала, Српска књижевна задруга, Београд, 2005);

${ }^{21} \mathrm{O}$ историјским изворима који су Андрићу послужили при писању докторске дисертације, али и прве збирке приповиједака, в. у: Вучковић 2011: 180. 
фигура, коју Андрић вјешто проналази у ковачу Циганину. Антрополошки песизмизам Мустафе Маџара и његова демонска предиспозиција одвели су га баш у руке демонском непријатељу који је окончао Мустафин живот. На крају, остаје прича о крволоку Мустафи, злосрећној индивидуалној фигури Андрићевих међуратних приповиједака - Мустафи о коме ће се дуго „причати и пјевати”.

\section{ЛИТЕРАТУРА}

Андрић 1981: И. Андрић, Немирна година, Сабрана дела Иве Андрића, Књига пета, Свјетлост-Просвета-Младост-Државна заложба СловенијеМисла-Побједа, Сарајево-Београд-Загреб-Љубљана-Скопје-Титоград.

Ахметагић 2011: J. Ахметагић, Пројективна идентификација Мустафе Маџара у: Свеске Задужбине Иве Андрића, год. 30, св. 28, Београд: Задужбина Иве Андрића.

Братић 1993: D. Bratić, Gluvo doba: predstava o noći u narodnoj religiji Srba, Beograd: Plato.

Вучковић 2011: Р. Вучковић, Велика синтеза, Београд-Ниш: КИЗ Алтера-Филозофски факултет.

Гербран - Шевалије 2009: A. Gerbran - Ž. Ševalije, Rečnik simbola, Novi Sad: Stylos art-Kiša.

Зечевић 1981: С. Зечевић, Митска бића српских предаға, Београд: Вук Караџић-Етнографски музеј .

Кољевић 2012: Н. Кољевић, Шекспир трагичар - Андрићево ремекдело, Београд-Бања Лука: Службени гласник-Академија наука и умјетности Републике Српске.

Кољевић 2012: С. Кољевић, Иво Андрић и народна књижевност, у: Дело Иве Андрића у контексту европске књижевности и културе, Београд: Задужбина Иве Андрића.

Кулишић и др. 1970: Ш. Кулишић - П. Ж. Петровић - Н. Пантелић, Српски митолошки речник, Београд: Нолит.

Пешић - Милошевић-Ђорђевић 1997: Р. Пешић - Н. МилошевићЂорђевић, Народна књижевност, Београд: Требник.

Rečnik književnih termina, 1986: (yp.) D. Živković, Beograd: Nolit.

Самарџија 2007: С. Самарџија, Увод у усмену књижевност, Београд: Народна књига.

Самарџић 1981: Р. Самарџић, Андрићев Мустафа Маиар у: Дело Иве Андрића у контексту европске књижевности и културе, Београд: Задужбина Иве Андрића. 
Толстој - Раденковић 2001: С. М. Толстој - Љ. Раденковић, (редактори), Словенска митологија - енциклопедијски речник, Београд: Zepter Book World.

Џаџић 1996: П. Џаџић, Иво Андрић: есеј, Београд: Завод за уџбенике и наставна средства.

Шутић 1981: М. Шутић, Архетипски обрасци у Мустафи Maиару, у: Дело Иве Андрића у контексту европске књижевности и културе, Београд: Задужбина Иве Андрића.

Небойша 3. Джорджевич

\section{ФОЛЬКЛЁРНЫЕ ЭЛЕМЕНТЫ В ПОВЕСТИ АНДРИЧА „МУСТАФА МАДЖАР”}

\section{Резюме}

Основой этой повести является фольклёрный подтекст, включающий архетипические и исторические основы, которыми Андрич использовался. Мустафа прошёл инициацию с человеческой к демонической природе его существа. Мы можем заключить по основе хронотипа, что Мустафа жил на границе двух миров. Демонической фигуре Мустафы может воспротивится другая демоническая фигура, кузнец Цыганин. Антропологический пессимизм Мустафы Маджара и его демонический характер отвели его в руки врага убившего его.

Ключевые слова: фольклор, мифология, демонологические элементы, архетипический образ, Мустафа Маджар, Иво Андрич. 